\title{
STARI GRAD NA OTOKU HVARU U HRVATSKOM NARODNOM PREPORODU - UPRAVNE STRUKTURE I POLITIČKI ŽIVOT ${ }^{1}$
}

\author{
UDK: 94 (497.5 Stari Grad) \\ 35 (497.5 Stari Grad) \\ DOI: $10.31141 /$ zrpfs.2021.58.141.907 \\ Pregledni rad \\ Primljeno: 1. prosinca 2020.
}

Uvodno se definira propast Mletačke Republike 1797., prva austrijska (1797. - 1806.) i francuska uprava (1806. - 1813.) nakon koje mletački posjedi (Mletačka Dalmacija i Boka kotorska) te nekadašnja Dubrovačka Republika dolaze u vlast Habsburške Monarhije koja formira upravnu jedinicu - Kraljevinu Dalmaciju, izravno podvrgnutu Beču.

Slijedi prikaz ustrojstva uprave i sudstva, političkih prilika do 1848. i 1861. kada se putem Dalmatinskog sabora uvode elementi parlamentarne demokracije i lokalne samouprave. kao i rezultati saborskih i općinskih izbora. Do pada Bachova neoapsolutizma 1861. općine nisu izbornopredstavničke ustanove. Nastaju dvije političke opcije, jedna se protivi ujedinjenju Dalmacije s Hrvatskom, traži talijanski jezik kao službeni, ističući isprva slavo-dalmatinski, a kasnije talijanski identitet (talijanaši, autonomaši). Nasuprot njima, dio građanstva, pretežito pučkog podrijetla, afirmira hrvatski identitet, traži sjedinjenje Dalmacije s Hrvatskom i Slavonijom, te uvođenje hrvatskog jezika u upravu, sudstvo, školstvo (narodnjaci, aneksionisti). Beč podupire autonomaše, ne želeći hrvatsku nacionalnu i državnu integraciju. Narodnjaci zbog izbornog sustava gube izbore za Dalmatinski sabor 1861. i 1864. godine, ali pobjeđuju na prvim općinskim izborima 1865. 1868., a 1870. i na izborima za Sabor.

U trećem dijelu obrađuju se specifičnosti Starog Grada u kojem se afirmacija narodnjaka odvija sporije. Stari Grad je od 1823. općina, dio kotara Hvar, a od 1852. sjedište kotarskog suda. Ugled mjesnih liječnika autonomaša (Gazzari i Nisiteo) poveo je mlađu generaciju hrvatskih pučana u njihov tabor, iako neki od vodećih narodnjaka podrijetlo vode iz Starog Grada (Vranković, Biankini i Ljubić). Narodnjaci pobjeđuju 1887. kada se afirmirala sljedeća generacija hrvatske inteligencije, sinova težaka, ribara i pomoraca ojačala razvojem gospodarstva - vinske trgovine i pomorstva u drugoj polovici 19. stoljeća.

Ključne riječi: Stari Grad, upravne i političke strukture, političke prilike 19. stoljeća

1 Zahvaljujem na korisnim napomenama prof. dr. sc. Željka Bartulovića s Pravnog fakulteta Sveučlišta u Rijeci. 


\section{UVOD - DRŽAVNOPRAVNE OKOLNOSTI U DALMACIJI DO 1813.}

Nakon gotovo četiri stoljeća pod Republikom Svetog Marka, otok Hvar je, kao i čitav mletački posjed na istočnoj obali Jadrana od Dubrovačke Republike pa do sjevernih jadranskih otoka, nazvan Mletačkom Dalmacijom. Nakon propasti Mletačke Republike, mirom u Campoformiju, zaključenim 19. listopada 1797. godine, pripao je nakratko Habsburškoj Monarhiji, a zatim od prosinca 1805. do prosinca 1813. godine Francuskoj, nakon čega je prešao u trajni austrijski posjed što će trajati do kraja Prvog svjetskog rata (1918.). ${ }^{2}$

Pripajanjem Dubrovačke Republike 1808., te Boke kotorske koja je do propasti Mletačke Republike bila dijelom njezina posjeda nazvanog Mletačka Albanija, pokrajina se protezala od otoka Raba na sjeveru do Paštrovića u budvanskom distriktu da bi konačan oblik iz vremena austrijske vladavine dobila nakon Berlinskog kongresa 1878. godine priključenjem Spiča, enklave na jugu hrvatskog etničkog arhipelaga ${ }^{3}$ koje se nalazi nadomak tada osmanskog Bara. ${ }^{4}$

Mletačka je Republika tijekom svoje vladavine proširivala posjede na hrvatskom tlu. Tako se na posjede stečene 1420. godine (acquisto vecchio, stara tečevina) nadovezivao posjed stečen nakon Karlovačkog mira 1699. godine (acquisto nuovo/nova tečevina ili Linea Grimani, Knin-Vrgorac) te posjedi nakon korekcije mletačko-turske granice oko Imotskoga 1723. godine (acquisto novissimo/najnovija stečevina ili Linea Mocenigo). ${ }^{5}$

U državnopravnom pogledu Habsburzi su 1805. godine dobili Dalmaciju mirovnim ugovorom kao kompenzaciju za područja koje je tim mirovnim ugovorom Austrija ustupila Francuskoj. Stoga nisu imali razloga voditi računa o starom državnopravnom odnosu na koji su se pozivali zagovornici ujedinjenja hrvatskih zemalja pa su ustrojili pokrajinu kao i druge tzv. "nasljedne zemlje". ${ }^{6}$ Prva austrijska uprava zatekla je srednjovjekovno ustrojstvo uprave i sudstva utemeljenom jednim dijelom na statutarnom pravu, a drugim dijelom na kolonijalnom sustavu Mletačke Republike pa je pristupila njezinu reformiranju unošenjem elemenata suvremenog sudstva. ${ }^{7} \mathrm{Na}$ čelu upravne vlasti nalazi se carski namjesnik (guverner) koji je izravno podređen središnjoj vladi u Beču. Carski namjesnik ujedno je i na čelu pokrajinske

2 Stančić, Nikša, "Otok Hvar u vrijeme hrvatskog narodnog preporoda u XIX. stoljeću", Zagreb, zbornik Otok Hvar, Matica hrvatska, str. 109-116.

3 Mrduljaš, Saša (2019.), "Etnički sastav naselja Boke kotorske prema popisu stanovništva iz 1900. godine", Migracijske i etničke teme, str. 241-276.

4 Trogrlić, Marko i Šetić, Nevio (2015.), Dalmacija i Istra u 19. stoljeću, Zagreb, Leykam international d.o.o., str. 29.

5 Bartulović, Željko, Povijest hrvatskog prava i države (nacrt predavanja za internu uporabu), Pravni fakultet Sveučilišta u Rijeci, 2008.; str. 17.

6 Bartulović, Željko, Povijest hrvatskog prava i države (nacrt predavanja za internu uporabu), Pravni fakultet Sveučilišta u Rijeci, 2008., str. 63-66, Bartulović, Željko i Ranđelović, Nebojša, Osnovi ustavne istorije jugoslovenskih naroda, Pravni fakultet u Nišu, Niš 2012., str. 140-141.

7 Maštrović, Vjekoslav (1959.), Razvoj sudstva u Dalmaciji, Zagreb, Jugoslavenska akademija znanosti i umjetnosti, str. 7. 
vlade koja ima samo savjetodavnu ulogu. Upravna vlast podijeljena je u 22 kotara čija su poglavarstva podređena namjesniku. Sudbena je vlast podijeljena na okruge sa sjedištima u Zadru, Splitu i Kotoru te Apelacijski sud koji se nalazio u tadašnjem glavnom gradu pokrajine Zadru, dok je vrhovni sud bio Kasacijski sud sa sjedištem u Beču. ${ }^{8}$ Ova reforma značajna je utoliko što je donijela odvajanje viših sudova od upravne vlasti te je time započet proces primjene načela podjele vlasti koji će se nastaviti i u narednim razdobljima. Načelo podjele vlasti provodi se u organizaciji Apelacijskog suda, a predviđa se i za okružne sudove uz dosljedno provođenje austrijske taktike očuvanja starih prava i privilegija. ${ }^{9}$

Nakon zaključenja Požunskog mira u prosincu 1805. godine, francuska vojska zaposjeda čitav dotadašnji austrijski posjed, a samo dva dana nakon ulaska francuske vojske u Zadar, 19. veljače 1806. godine, zapovjednik francuskih snaga general Dumas izdaje proglas o sjedinjenju Dalmacije s Talijanskim Kraljevstvom pod francuskim suverenitetom sa sjedištem u Milanu na čijem se čelu kao potkralj nalazio Napoleonov pastorak Eugen Beauharnais, dok je uloga kralja te državine pripadala francuskom caru Napoleonu Bonaparteu. ${ }^{10}$ Francuska uprava nastavila je s reformiranjem zatečenog stanja te je uvela načela jednakosti pred zakonom i odvojenosti sudbene od upravne vlasti. ${ }^{11} \mathrm{Na} c ̌ e l u$ uprave je generalni providur podređen potkralju u Milanu. Vrhovna je uprava pokrajinska vlada sa 6 odjela (unutrašnji poslovi, prosvjeta, pravosuđe, računovodstvo, financije i vojska). Generalni savjet od 48 članova savjetodavni je organ vlade. Pokrajina je podijeljena u upravnom smislu na 4 okruga sa sjedištima u Zadru, Šibeniku, Splitu i Makarskoj, na čelu s izaslanikom, a okruzi na 17 kotara (kantona) na čelu s podizaslanikom. Na dnu upravne piramide su općine (seoske i gradske) s načelnikom i imenovanim općinskim vijećima. Sudstvo je dosljedno odvojeno od uprave po načelima Francuske revolucije. Predviđene su tri razine sudovanja na razini pokrajine. Najniži su mjesni (pomirbeni) sudovi sa sjedištima u sjedištu kotara, viši su okružni sudovi sa sjedištima u Zadru, Splitu i Dubrovniku, dok je sud najviše razine Apelacijski sud sa sjedištem u glavnom gradu pokrajine Zadru. Najviša instanca s ovlastima vrhovnog suda jest Kasacijski sud sa sjedištem u Milanu. ${ }^{12}$

Nakon zaključenja mira u Schoenbrunu 1808. godine, Francuska proširuje posjed na središnju Istru, bansku Hrvatsku južno od Save do ušća Une u Savu te slovenske zemlje. Od tih područja formirane su 1809. godine Ilirske pokrajine sa sjedištem u Ljubljani. Dalmacija je jedna od sedam upravnih pokrajina. Ilirske pokrajine bile su autonomna jedinica u okviru Francuskog Carstva. Na čelu im se

8 Bartulović, Željko, Povijest hrvatskog prava i države (nacrt predavanja za internu uporabu), Pravni fakultet Sveučilišta u Rijeci, 2008., str. 63-66, Bartulović, Željko i Ranđelović, Nebojša, Osnovi ustavne istorije jugoslovenskih naroda, Pravni fakultet u Nišu, Niš 2012., str. 140-141.

9 Maštrović, Vjekoslav (1959.), Razvoj sudstva u Dalmaciji, Zagreb, Jugoslavenska akademija znanosti i umjetnosti, str. 44.

10 Isto, str. 45.

11 Isto, str. 7 i 51-59.

12 Bartulović, Željko, Povijest hrvatskog prava i države (nacrt predavanja za internu uporabu), Pravni fakultet Sveučilišta u Rijeci, 2008., str. 62-63, Bartulović, Željko i Ranđelović, Nebojša, Osnovi ustavne istorije jugoslovenskih naroda, Pravni fakultet u Nišu, Niš 2012., str. 139.. 
nalazio generalni guverner kojeg je imenovao car. U toj dužnosti bila je objedinjena i vojna i civilna vlast. Na čelu svake pokrajine nalazio se intendant. Svaka pokrajina bila je podijeljena na kotareve kojima je upravljao podintendant. ${ }^{13} \mathrm{U}$ tom smislu provedena je promjena upravnog ustroja u Dalmaciji pa je sada imala 5 kotareva sa sjedištima u Zadru, Splitu, Sibeniku, Makarskoj i Hvaru. U ovom razdoblju formirana je i pokrajina sa sjedištem u Dubrovniku od područja nekadašnje Dubrovačke Republike koja je netom prestala postojati te Boke kotorske, s tri kotara sa sjedištima u Dubrovniku, Korčuli i Kotoru. ${ }^{14}$ Sudbena vlast i u ovom je razdoblju dosljedno odvojena od uprave, sukladno načelu trodiobe vlasti. Sudstvom upravlja povjerenik za pravosuđe koji je zajedno s povjerenikom za financije i glavnim guvernerom član vlade koja upravlja Ilirskim pokrajinama. Zajedno s dva člana Apelacijskog suda u Ljubljani čini Malo vijeće koje sudi u upravnim stvarima, što je začetak upravnog sudovanja. Zadržan je sličan ustroj sudovanja na svim razinama s izmjenama koje su pratile izmjenu teritorijalnog i upravnog ustroja pa tako pored pomirbenih sudova na najnižoj razini postoje okružni sudovi sa sjedištima u Zadru, Splitu, Dubrovniku i Kotoru te prizivni sudovi sa sjedištima u Zadru i Dubrovniku za područje novoformirane pokrajine. U Ljubljani je bilo sjedište trećeg prizivnog suda koje je obuhvaćalo područje ostatka Ilirskih pokrajina te Apelacijskog suda, vrhovnog suda za čitavo područje Ilirskih provincija. U ovom razdoblju uvedeno je načelo akuzatornosti u kazneno sudovanje tako da je uvedena uloga državnog odvjetnika koji poduzima kazneni progon i zastupa optužbu u predmetima javnih delikata. ${ }^{15}$

U čitavom razdoblju francuske uprave, vlasti su, posebno u prvom dijelu dok je generalni providur bio Vicenzo Dandolo, nastojale ukinuti pravni partikularizam statutarnog prava. Unifikacija nije bila laka, a pojavio se otpor uvođenju instituta francuskog prava kod uvođenja građanskog umjesto crkvenog braka te kod nasljednog prava zbog običaja da se ne priznaje jednakost muških i ženskih potomaka zbog čega će u tom dijelu biti ograničeno uvođenje Code civil. U svrhu unifikacije donesene su 1806. godine četiri uredbe; prvom su ukinuta vlastelinska prava, a drugom, tzv. Girmanijevim zakonom, težaci su postali vlasnici zemljišta koje obrađuju uz obvezu plaćanja desetine državi. Trećom je uredbom proširen Konkordat između Rimokatoličke crkve i Francuskog Carstva o sklapanju brakova na područje Dalmacije, a četvrtom je uveden Code civile, osim za obiteljsko i nasljedno pravo. ${ }^{16}$

13 Isto.

14 Maštrović, Vjekoslav (1959.), Razvoj sudstva u Dalmaciji, Zagreb, Jugoslavenska akademija znanosti i umjetnosti, str. 58.

15 Bartulović, Željko, Povijest hrvatskog prava i države (nacrt predavanja za internu uporabu), Pravni fakultet Sveučilišta u Rijeci, 2008., str. 62-63, Bartulović, Željko i Ranđelović, Nebojša, Osnovi ustavne istorije jugoslovenskih naroda, Pravni fakultet u Nišu, Niš 2012., str. 139.

16 Isto. 


\section{STARI GRAD, HVAR I DALMACIJA U HRVATSKOM NARODNOM PREPORODU - UPRAVNE STRUKTURE I POLITIČKI ŽIVOT}

\subsection{Početak druge austrijske uprave u Dalmaciji 1813.}

Druga austrijska uprava nastavila je s reformiranjem uprave i sudstva na način da postupno likvidira francuski sustav uključujući i zakone, prilagođavajući upravni i sudski sustav svojim potrebama i ciljevima. ${ }^{17}$

Već od prosinca 1813. godine ima na čelu civilne i vojne uprave namjesnika (guvernera). Uz namjesnika bila je zemaljska vlada koja od 1850. godine dobiva naziv Namjesništvo. Proglasom od 3. kolovoza 1816. godine Dalmacija dobiva status krunovine unutar Habsburške Monarhije izravno podvrgnute Beču kao i za vrijeme prve austrijske uprave. ${ }^{18}$

Područje Dalmacije 1815. godine obuhvaćeno je u 4 okruga sa sjedištima u Zadru Splitu, Dubrovniku i Kotoru, a svaki okrug dijeli se na kotareve, njih ukupno 28. Isto tako, utemeljen je Prizivni sud u Zadru kao vrhovni sud za pokrajinu i 4 kolegijalna (okružna) suda sa sjedištima u Zadru, Splitu, Dubrovniku i Kotoru te 24 kotarska suda. ${ }^{19}$

\subsection{Ustrojstvo uprave i sudstva u vrijeme druge austrijske uprave}

Već pod kraj mletačkog razdoblja općine su izgubile značenje i autonomiju koju su imale u srednjem vijeku tako da i u doba prve austrijske uprave i u doba francuske uprave općine nisu niti izbornopredstavničke ustanove, niti više imaju sadržaj ni formu autonomne komune srednjeg vijeka. ${ }^{20}$

U vrijeme druge austrijske uprave prva organizacija općina provedena je 1823. godine temeljem odluke donesene dvije godine ranije po uzoru na sustav iz tada austrijske pokrajine Lombardija-Veneto iz 1816. godine. ${ }^{21}$

Do ukinuća okružja kotarevi ili preture bili su pod neposrednom upravom okružnih poglavarstava. Na čelu kotareva bili su pretori koji su pak nadzirali općine. Nakon što su krajem 1865. godine ukinuta okružja, funkciju okružnih poglavarstava dijelom preuzimaju preture, a dijelom Namjesništvo. ${ }^{22}$

17 Maštrović, Vjekoslav (1959.), Razvoj sudstva u Dalmaciji, Zagreb, Jugoslavenska akademija znanosti i umjetnosti, str. 7 i 60-67.

18 Isto, str. 67.

19 Isto, str. 67.

20 Foretić, Dinko (1969.), "Borba za ponarođivanje općina u Dalmaciji (1865-1900)", zbornik Hrvatski narodni preporod u Dalmaciji, Zagreb, Matica hrvatska, str. 89.

21 Isto, str. 89-90.

22 Isto, str. 90. 
Prema propisima o organizaciji iz 1821. godine općine su bile sastavni dio upravno-političkog sustava te pod neposrednom upravom kotarskih vlasti. Mjesta u kojima je bilo sjedište okružnih ili kotarskih vlasti imala su i općinsko vijeće, u sjedištima okruga sa po 15 članova, u sjedištima kotareva sa po 9 članova te općinsku upravu na čelu s načelnikom uz dvoje prisjednika u sjedištima općina odnosno četiri prisjednika u sjedištima kotareva. Ostale općine imale su samo načelnika (suca), a veće općine i podnačelnika (podsuca).

Naselja s najmanje 25 obitelji imala su seoskog glavara podređenog općinskoj upravi. Načelnike općina kao i prisjednike, gradske suce i podsuce birala je vlada, dok je načelnike ujedno i pretore Zadra, Splita, Dubrovnika i Kotora imenovao kralj. ${ }^{23}$

Dakle, iz priložene organizacijske strukture vidljivo je kako do 1865. godine općine nisu imale nikakvu autonomiju te kako su bile potpuno podložne središnjoj vlasti.

\subsection{Političke i društvene prilike u Dalmaciji do 1848. godine}

Premda su Hrvati pad Mletačke Republike dočekali tek s tragovima nacionalne svijesti, dok se o narodnoj povijesti nije znalo gotovo ništa, ipak, generala Rukavinu, Hrvata koji je predvodio austrijske trupe, puk je dočekao s oduševljenjem.

Po savjetu Ignjata Bakotića, župnika iz Kaštel Gomilice, nastao je pokret koji je, predvođen svećenstvom i plemstvom, tražio ujedinjenje s Hrvatskom pod ugarskom krunom. Iz tog razloga podnesena je adresa hrvatskom banu Ivanu Erdödyju i austrijskom caru, međutim ministar Thugut nije bio suglasan sa sadržajem adrese te je na taj način izvijestio cara. ${ }^{24}$

Treba naglasiti kako Austrija nije namjeravala sjediniti Dalmaciju s banskom Hrvatskom jer bi sjedinjenjem hrvatskih zemalja Hrvatska postala snažniji politički faktor u Monarhiji, a ojačao bi položaj i ugarske krune koja je vladala banskom Hrvatskom. Štoviše, već u vrijeme prve austrijske uprave, bečka dvorska kancelarija donijela je odluku u kojoj se navodi kako je Austrija dobila Dalmaciju mirom u Campoformiju kao kompenzaciju za teritorije koje je prepustila Italiji i Nizozemskoj, a ne temeljem nekog starog državnopravnog odnosa zbog čega car nije obvezan dati Dalmaciju Ugarskoj čime je jasno navijestio smjer budućeg austrijskog odnosa prema sjedinjenju hrvatskih zemalja. ${ }^{25}$

Austrija je u vrijeme druge uprave Dalmacijom nastavila proces započet u doba francuske uprave, proces stvaranja intelektualnog sloja odgojenog u talijanskoj kulturi. ${ }^{26}$

23 Isto, str. 91.

24 Pilar, Ivo (1990.), Južnoslavensko pitanje, prikaz cjelokupnog pitanja, Varaždin, Hrvatska demokratska stranka, Podružnica Varaždin, str. 250-251.

25 Novak, Grga (2004.), Prošlost Dalmacije, knjiga druga, Split, Marjan tisak d.o.o., str. 60-61.

26 Isto, str. 90. 
Prethodno, Mletačka Republika nije niti pokušala talijanizirati stanovnike hrvatske obale Jadrana jer u tom razdoblju nije postojala talijanska nacionalna ideja, a mletačkoj je eliti bilo važno da stanovnici njihovih posjeda budu lojalni podanici te nije vodila računa o jeziku ni o kulturi svojih podanika. Pored toga, Mletačkom je Republikom vladala isključivo njihova aristokracija dok su svi drugi bili građani drugog reda, tako da Hrvati nisu mogli doći do pozicija unutar državnih struktura osim nižih časničkih u mletačkoj vojsci, pa su uvijek bili upućeni na svoje komune. One malobrojne školovane u talijanskim sveučilištima smatrali su isključivo Hrvatima te ih nisu nikada smatrali ravnopravnima. ${ }^{27}$

Dakle, Austrija je stvarala ono što Mletačka Republika nije za gotovo četiri stoljeća vladavine: nametnula je dalmatinskim Hrvatima talijanski jezik u javnom životu. ${ }^{28}$ Treba naglasiti i to kako se Dalmacija našla u velikoj carevini u kojoj su bile i talijanske pokrajine Lombardija i Veneto gdje upravo u tom razdoblju napreduju književnost i znanost, kako se uski sloj elite školuje upravo u Padovi i u drugim talijanskim sveučilištima te kako zbog nedostatka obrazovanih ljudi u Dalmaciju Austrija dovodi činovnike i časnike iz tih pokrajina. ${ }^{29}$

Također, za prijam u državnu službu u Dalmaciji austrijske su vlasti tražile poznavanje talijanskog jezika; prve škole bile su na talijanskom jeziku. Od ovog sloja ljudi pod utjecajem državne vlasti stvoren je krug ljudi odgojenih u talijanskom duhu i talijanskoj kulturi koji se opirao ideji ujedinjenja s banskom Hrvatskom. ${ }^{30}$

Grga Novak navodi kako se većinom radi o "poluinteligenciji" koja je "često tek primirisala ljepotu talijanskog genija, ali se i time ponosila, prezrevši svoj narod i svoj materinji jezik". Ističe kako se taj sloj stanovnika dalmatinskih gradića nikada nije priznavao Talijanima, "oni su bili Dalmatinci koji su priznavali svoje hrvatsko podrijetlo, ali su ga nazivali "dalmatinskim" ili slaveno-dalmatinskim, i pri tom isticali svoju talijansku obrazovanost". ${ }^{31}$

Dok je za mletačke vlasti talijanski jezik bio jezik trgovine, pomorstva pa i kulture, austrijska vlast ga je učinila jezikom javnog života, oslanjajući se pri tome na osobe obrazovane na talijanskom jeziku ${ }^{32}$ i doseljenike $s$ talijanskog govornog područja ${ }^{33}$ koje je u to vrijeme bilo pod austrijskom vlašću.

Ipak, većina osoba koja je istupala u javnosti u pretpreporodnom razdoblju izražavala je domoljublje povezujući talijansku kulturu, osjećaj hrvatske etničke pripadnosti, općenito slavenstvo uz užu dalmatinsku zavičajnost zbog čega u toj

27 Isto, str. 88-89.

28 Novak, Grga (2004.), Prošlost Dalmacije, knjiga druga, Split, Marjan tisak d.o.o., str. 91.

29 Isto, str. 91.

30 Isto, str. 91.

31 Isto, str. 91.

32 Stančić, Nikša, "Otok Hvar u vrijeme hrvatskog narodnog preporoda u XIX stoljeću", Zagreb, zbornik Otok Hvar, Matica hrvatska, str. 110

33 Novak, Grga (2004.), Prošlost Dalmacije, knjiga druga, Split, Marjan tisak d.o.o., str. 91. 
fazi razvitka nacionalne svijesti, tzv. "slavo-dalmatinstvo" nije imalo protuhrvatski sadržaj. ${ }^{34}$

\subsection{Politička gibanja od 1848. do 1861. godine}

Događanja iz 1848. godine u banskoj Hrvatskoj kao i na čitavom području Monarhije slabo su se osjetila u Dalmaciji. Hrvatski je sabor u "Zahtijevanjima naroda" tražio sjedinjenje banske Hrvatske i Dalmacije, a postojali su pojedinačni pozivi gradova Varaždina, Zagreba i Siska te Križevačke županije, međutim akteri tih događaja nisu znali da u dalmatinskim općinama ne upravljaju predstavnici domicilnog stanovništva već elita odgojena u talijanskim školama i činovnici što ih je dovela Austrija koji uglavnom ne govore hrvatski jezik. ${ }^{35}$

Iste godine Mletačka Republika proglasila je neovisnost od Habsburške Monarhije te je upućen poziv od predsjednika provizorne vlade Manina za priključenje područja koja su do 1797. godine bila dijelom Mletačke Republike, međutim ti proglasi nisu imali nikakva utjecaja na hrvatski puk. ${ }^{36}$

$\mathrm{Na}$ otoku Hvaru nisu se osjetila politička gibanja 1848., međutim vrijedno je spomenuti kako je prilikom imenovanja hrvatskog bana Josipa Jelačića za gubernatora Dalmacije u prosincu 1848. godine, u Starom Gradu u društvenom okupljalištu Casinu izvješen natpis njemu u čast, a u susjednoj Jelsi na brodu obitelji Duboković zavijorila je hrvatska trobojnica. ${ }^{37}$

\subsection{Ustavno razdoblje - postupno uvođenje elemenata parlamentarne demokracije i lokalne samouprave}

Nakon pada Bachova apsolutizma i uvođenja ustavnih sloboda, Monarhija se našla pred izborom dvaju koncepata, nacionalne njemačke centralizirane države $i$ srednjoeuropskog federalizma. Car Franjo Josip priklonio se konceptu federalizma, saveza povijesnih kraljevina od kojih bi svaka imala svoj zemaljski sabor i slala svoje predstavnike u središnje predstavničko tijelo. ${ }^{38}$ Tako je čitava Habsburška Monarhija podijeljena na 21 pokrajinu od kojih je svaka imala predstavnička tijela te tijela izvršne vlasti za dodijeljene autonomne poslove. Međutim, središnje vlasti žele osigurati njemačku većinu u središnjem predstavničkom tijelu, Carevinskom vijeću te se posebno planira raspored mandata u Vijeću i pokrajinskim saborima. Formirane su kurije veleposjednika, gradskih općina (građani), trgovačko-obrtnih

\footnotetext{
34 Stančić, Nikša, "Otok Hvar u vrijeme hrvatskog narodnog preporoda u XIX stoljeću", Zagreb, zbornik Otok Hvar, Matica hrvatska, str. 112.

35 Novak, Grga (2004.), Prošlost Dalmacije, knjiga druga, Split, Marjan tisak d.o.o., str. 99-103.

36 Isto, str. 103.

37 Stančić, Nikša, Otok Hvar u vrijeme hrvatskog narodnog preporoda u XIX stoljeću, str. 112.

38 Trogrlić, Marko i Šetić, Nevio (2015.), Dalmacija i Istra u 19. stoljeću, Zagreb, Leykam international d.o.o., str. 47.
} 
komora (trgovci, obrtnici i industrijalci) i seoskih općina (seljaci). Veći broj mandata imaju kurije čiji su birači većinom njemačke ili talijanske narodnosti, jer ukupan broj talijanskih zastupnika u Carevinskom vijeću i saborima ne bi ugrozio njemačku dominaciju čak ni ako bi koalirali sa slavenskim zastupnicima (Poljaci, Česi, Slovaci, Hrvati, Slovenci, Srbi). Iako je udovoljen zahtjev građanstva za samoupravom, na pokrajine ipak nisu prenesene značajnije ovlasti, ali je financiranje pokrajinskih poslova preneseno na pokrajine. Ostavljena je velika mogućnost utjecaja središnje vlasti na rad pokrajinskih sabora, tako da je car imenovao predsjednika sabora, a mogao je svakom aktu sabora uskratiti suglasnost. ${ }^{39}$

Tako je i u Kraljevini Dalmaciji te 1861. godine utemeljen Pokrajinski sabor te će se uskoro rasplamsati političke borbe između dvaju suprotstavljenih koncepata. ${ }^{40}$ Vodeću ulogu u političkom životu preuzelo je gradsko i građansko stanovništvo koje je favorizirao izborni zakon. ${ }^{41} \mathrm{Na}$ čelu Sabora je predsjednik kojeg iz redova zastupnika imenuje car. Sabor saziva i raspušta car na prijedlog središnje vlade. Sabor bira izvršno tijelo, zemaljski odbor od 4 člana, kojem je na čelu predsjednik Sabora. Na čelu državne vlasti carski je namjesnik u Zadru sa zemaljskom vladom (Namjesništvom), oboje su podređeni središnjoj vladi u Beču. Namjesnici su do 1902. godine bili visoki časnici u pravilu u činu generala koji su ujedno bili na čelu vojske u Dalmaciji. ${ }^{42}$

Sabor je bio nadležan za poslove poljoprivrede, javne građevine, pokrajinske zaklade i zavode, osnovno školstvo, zdravstvo i socijalnu skrb te donošenje pokrajinskog proračuna. Zakoni su mogli stupiti na snagu tek nakon careve sankcije, a u vrijeme postojanja Sabora (1861. - 1918.) mnoge i nije potvrdio. Predviđeno je i kako Sabor za financiranje poslova može uvesti pokrajinski prirez u visini od $10 \%$ izravnih poreza. ${ }^{43}$

Stupanjem na snagu Općinskog pravilnika, objavljenog 30. srpnja 1864. godine, općine dobivaju elemente lokalne samouprave, ${ }^{44}$ a istovremeno kroz tzv. povjereni djelokrug poslova sudjeluju u državnoj upravi obavljajući poslove koje im propisuju državni i pokrajinski zakoni. ${ }^{45}$

39 Bartulović, Željko, Povijest hrvatskog prava i države (nacrt predavanja za internu uporabu), Pravni fakultet Sveučilišta u Rijeci, 2008., str. 63-66, Bartulović, Željko i Ranđelović, Nebojša, Osnovi ustavne istorije jugoslovenskih naroda, Pravni fakultet u Nišu, Niš 2012., str. 140-141.

40 Trogrlić, Marko i Šetić, Nevio (2015.), Dalmacija i Istra u 19. stoljeću, Zagreb, Leykam international d.o.o., str. 48.

41 Stančić, Nikša, "Otok Hvar u vrijeme hrvatskog narodnog preporoda u XIX stoljeću", Zagreb, zbornik Otok Hvar, Matica hrvatska, str. 112.

42 Bartulović, Željko, Povijest hrvatskog prava i države (nacrt predavanja za internu uporabu), Pravni fakultet Sveučilišta u Rijeci, 2008., str. 63-66, Bartulović, Željko i Ranđelović, Nebojša, Osnovi ustavne istorije jugoslovenskih naroda, Pravni fakultet u Nišu, Niš 2012., str. 140-141.

43 Isto.

44 Novak, Grga (2004.), Prošlost Dalmacije, knjiga druga, Split, Marjan tisak d.o.o., str. 145.

45 Foretić, Dinko (1969.), "Borba za ponarođivanje općina u Dalmaciji (1865-1900)", zbornik Hrvatski narodni preporod u Dalmaciji, Zagreb, Matica hrvatska, str. 93. 
Također, općine postaju i izborno-predstavnička tijela. ${ }^{46}$ Općinski izbori i osvajanje vlasti u općinama bilo je od posebnog značaja za ostvarenje ciljeva Hrvatskog narodnog preporoda jer su prema novom zakonodavstvu općinska vijeća imala zadnju riječ u odlučivanju o jeziku u školama i u općinskoj upravi. ${ }^{47}$

Izbornim pravilnikom koji je stupio na snagu u isto vrijeme kada i Općinski pravilnik regulirano je aktivno i pasivno biračko pravo. Osnovicu biračkog prava činilo je plaćanje određene količine poreza, a iznimno je postojalo povlašteno pravo određenih osoba poput svećenika, državnih službenika, učitelja, osoba sa završenim fakultetom, vojnih osoba, pomorskih kapetana. Izborno pravo imale su i pravne osobe koje su plaćale porez u određenoj općini.

Izborna tijela osnivala su se prema ukupnoj svoti godišnjeg poreza te su se dijelila na tri dijela. Prvo izborno tijelo činile su uglavnom osobe s osobnim izbornim pravom, drugo tijelo osobe čiji je porez dosezao svotu poreza drugog dijela, a treće izborno tijelo činili su svi ostali birači. Budući da je svako tijelo biralo jednak broj vijećnika, glas razmjerno malog broja birača u prvom i drugom tijelu vrijedio je više od glasa birača u trećem tijelu. ${ }^{48} \mathrm{U}$ praksi je to značilo da je izborni sustav pogodovao odnarođenoj eliti od koje se očekivala potpora režimu i autonomiji. ${ }^{49}$

Izborni je zakon predvidio da Sabor ima 43 zastupnika od kojih 41 biranog i 2 virilista (rimokatoličkog nadbiskupa i pravoslavnog episkopa). Postoje 4 kurije pri čemu je bitan porezni cenzus. Kurija veleporeznika, čiji članovi plaćaju 100 ili 50 fiorina izravnog poreza, bira 10 zastupnika. Trgovačko-obrtničke komore biraju 3 zastupnika (zadarska i splitska komora po jednog zastupnika, dubrovačka i kotorska zajedno jednog). Gradovi sa $10 \%$ stanovništva biraju 8, a kurija vanjskih (seoskih) općina sa $90 \%$ stanovnika 20 zastupnika. Glasovanje u prve dvije kurije je neposredno. U kuriji gradova građani se prema visini plaćenog izravnog poreza dijele u 3 skupine od kojih samo prve dvije biraju. U četvrtoj kuriji bira se posredno, na 500 stanovnika bira se jedan izbornik, a oni onda biraju zastupnike. Biračko pravo imaju muškarci od 24 godine, ali samo prve $2 / 3$ prema visini porezne obveze, uz minimalan iznos od 1 fiorina. U kuriji gradova i kuriji vanjskih općina biračko su pravo imali i činovnici, pomorski pisari i kapetani, svećenici, učitelji i profesori u javnoj službi, časnici i osobe s doktoratom. Zakonom je predviđeno kako mandat zastupnika traje šest godina. Tijekom trajanja Sabora znalo se dogoditi da se sjednice, protuzakonito, ne sazovu ni po tri godine. Sabor nije sazivan nakon 1912. godine iako je formalno postojao do $1918 .^{50}$

46 Novak, Grga (2004.), Prošlost Dalmacije, knjiga druga, Split, Marjan tisak d.o.o., str. 145-146.

47 Trogrlić, Marko i Šetić, Nevio (2015.), Dalmacija i Istra u 19. stoljeću, Zagreb, Leykam international d.o.o., str. 51.

48 Foretić, Dinko (1969.), "Borba za ponarođivanje općina u Dalmaciji (1865-1900)", zbornik Hrvatski narodni preporod u Dalmaciji, Zagreb, Matica hrvatska, str. 94-95.

49 Bartulović, Željko, Povijest hrvatskog prava i države (nacrt predavanja za internu uporabu), Pravni fakultet Sveučilišta u Rijeci, 2008., str. 63-66, Bartulović, Željko i Ranđelović, Nebojša, Osnovi ustavne istorije jugoslovenskih naroda, Pravni fakultet u Nišu, Niš 2012., str. 140-141.

50 Isto. 
Zakonom od 19. svibnja 1868. godine izvršena je reorganizacija uprave. Prije svega, lokalna uprava reorganizirana je u 12 kotareva, a sudstvo na 33 kotarska suda. Na kotareve je prešao dio nadležnosti kotarskih sudova koje se odnose na upravnopolitičke poslove. Međutim, najvažnija je izmjena potpuno odvajanje sudbene vlasti od političke vlasti ${ }^{51}$ čime je dovršen proces započet još u vrijeme francuske uprave.

\subsection{Političke prilike na početku ustavnog razdoblja}

Na početku preporodnih kretanja vodeća gradska i građanska skupina, talijanski obrazovana, usmjerena je slavo-dalmatinski. U vremenu uspostave ustavnih sloboda i slobode političkog djelovanja, nakon završetka neoapsolutizma u Habsburškoj Monarhiji, kada se obnovilo pitanje sjedinjenja Dalmacije s banskom Hrvatskom i pitanje službenog jezika, ta skupina je zahtijevala političku odvojenost Dalmacije od banske Hrvatske i zagovarala očuvanje talijanskog jezika kao službenog u Dalmaciji.

Oslonac za takvu politiku našla je u Beču koji zbog zamršenih odnosa s Ugarskom nije htio dopustiti sjedinjenje Dalmacije s banskom Hrvatskom. Ova skupina oblikovala je već 1860. godine tzv. "autonomaški program". Ovom programu pridružila se i malobrojna i u počecima pritajena opcija koja se smatrala dijelom talijanske nacije. ${ }^{52}$

Dio građanstva, pa i onog školovanog na talijanskim sveučilištima u sjevernoj Italiji, ipak je od talijanskog preporodnog pokreta preuzeo model prema kojemu će voditi pokret za afirmaciju vlastitog nacionalnog identiteta. Ova politička opcija će kroz novoutemeljenu Narodnu stranku isticati zahtjev za sjedinjenje Dalmacije s banskom Hrvatskom i uvođenje hrvatskog jezika kao službenog u upravu, sudstvo, školstvo i javni život.

Međutim, zbog velikog dijela autonomaša koji su zastupali slavo-dalmatinsku ideju, ali nisu unaprijed bili protiv sjedinjenja Dalmacije s banskom Hrvatskom ako bi se očuvali elementi autonomije Dalmacije, gradski narodnjaci su, iako su osjećali svoju hrvatsku etničku pripadnost, stavili u prvi plan slavensku ideju. ${ }^{53}$

\subsection{Saborski i općinski izbori i djelomično ostvarenje ciljeva}

Kompliciran izborni kurijalni sustav prema kojemu je tek $15 \%$ stanovništva imalo pravo glasa ${ }^{54}$ na prvim izborima za Dalmatinski sabor održanima 1861.

\footnotetext{
${ }^{51}$ Foretić, Dinko (1969.), "Borba za ponarođivanje općina u Dalmaciji (1865-1900)", zbornik Hrvatski narodni preporod u Dalmaciji, Zagreb, Matica hrvatska, str. 49.

52 Stančić, Nikša, "Otok Hvar u vrijeme hrvatskog narodnog preporoda u XIX stoljeću", Zagreb, zbornik Otok Hvar, Matica hrvatska, str. 112.

53 Isto, str. 113.

54 Stančić, Nikša, "Otok Hvar u vrijeme hrvatskog narodnog preporoda u XIX stoljeću", Zagreb, zbornik Otok Hvar, Matica hrvatska, str. 112.
} 
godine, donio je uvjerljivu pobjedu autonomašima na razini pokrajine jer je 15.000 Talijana biralo 28 zastupnika u Sabor, a preko 400.000 Hrvata samo 15 zastupnika. ${ }^{55}$

Pored toga, nakon zaključenja austro-ugarske nagodbe 1867. godine, Dalmacija je pripala u austrijski, a Kraljevina Hrvatska i Slavonija u mađarski dio Monarhije ${ }^{56}$ što je stvorilo ozbiljnu ustavno-pravnu zapreku ostvarenja glavnog preporodnog cilja, ujedinjenja Kraljevine Dalmacije s banskom Hrvatskom. Zbog toga narodnjaci, ne odustajući od krajnjeg cilja, svoje aktivnosti usmjeravaju kroz proces daljnjeg nacionalnog osvješćivanja kroz narodne čitaonice i tiskana izdanja na hrvatskom i talijanskom jeziku, borbu za uvođenje hrvatskog jezika prvo u općine, škole, a zatim u sudstvo i javnu upravu. ${ }^{57}$

Nakon pobjede narodnjaka na prvim općinskim izborima koji su se održavali između 1865. i 1868. godine u više od pola općina, većina općina donosi odluku da će službeni jezik općine, kao i nastavni jezik u školama na području općine biti hrvatski, ${ }^{58}$ a na tom je tragu i naputak namjesnika generala Franje Filipovića o izjednačavanju hrvatskog i talijanskog jezika u školama. ${ }^{59}$

Nakon pobjede Narodne stranke na saborskim izborima 1870. godine, narodnjaci više neće ispuštati saborsku većinu. To se odrazilo na rezultate općinskih izbora u narednom razdoblju pa će narodnjaci povećati broj općina u kojima ostvaruju većinu tako da će 1875. godine u narodnjačkim rukama biti 59 od ukupno 80 općina. ${ }^{60}$

Preostat će još glavni grad pokrajine Zadar koji će u rukama talijanaške manjine ostati do propasti Austro-Ugarske Monarhije te Split, Trogir, Vis i Stari Grad na Hvaru u kojima su se autonomaši zadržali na vlasti do 80-ih godina 19. stoljeća. Narodnjačka pobjeda na općinskim izborima u Splitu, najvećem i gospodarski najrazvijenijem gradu pokrajine 1882. godine, ${ }^{61}$ predstavljat ce vrhunac Hrvatskog narodnog preporoda u Dalmaciji i stabilizaciju hrvatske nacionalne ideje.

Tijekom narednih godina predstoji postupno osvajanje institucija i jačanje položaja hrvatskog jezika u institucijama. U Saboru je hrvatski jezik izjednačen s talijanskim nakon pobjede narodnjaka 1870. godine, ${ }^{62}$ a službenim jezikom postaje 1883. godine. ${ }^{63}$

55 Pilar, Ivo (1990.), Južnoslavensko pitanje, prikaz cjelokupnog pitanja, Varaždin, Hrvatska demokratska stranka, Podružnica Varaždin, str. 254;

56 Trogrlić, Marko i Šetić, Nevio (2015.), Dalmacija i Istra u 19. stoljeću, Zagreb, Leykam international d.o.o., str. 53.

57 Isto, str. 59.

58 Foretić, Dinko (1969.), "Borba za ponarođivanje općina u Dalmaciji (1865-1900)", zbornik Hrvatski narodni preporod u Dalmaciji, Zagreb, Matica hrvatska, str. 111.

59 Cetnarowicz, Antoni (2006.), Narodni preporod u Dalmaciji, Zagreb, Srednja Europa, str. 123.

60 Foretić, Dinko (1969.), "Borba za ponarođivanje općina u Dalmaciji (1865-1900)", zbornik Hrvatski narodni preporod u Dalmaciji, Zagreb, Matica hrvatska, str. 133.

${ }_{61}$ Trogrlić, Marko i Šetić, Nevio (2015.), Dalmacija i Istra u 19. stoljeću, Zagreb, Leykam international d.o.o., str. 58.

62 Novak, Grga (2004.), Prošlost Dalmacije, knjiga druga, Split, Marjan tisak d.o.o., str. 158.

63 Isto, str. 167-168. 
U sudstvu je hrvatski jezik izjednačen s talijanskim od 1870 . godine ${ }^{64}$ a što se tiče uprave, nakon niza propisa koji su omogućavali upotrebu hrvatskog jezika, 26. travnja 1909. godine sedam ministarstava središnje vlade donosi naredbu kojom je hrvatskom jeziku osigurana upotreba u sudstvu i upravi. ${ }^{65}$

Hrvatski narodni preporod u Dalmaciji nije ostvario svoj krajnji cilj, sjedinjenje Dalmacije s Hrvatskom, ali je postigao afirmaciju hrvatskog nacionalnog identiteta do pohrvaćenja javnog života te je postavljen čvrst temelj za ostvarenje sjedinjenja Dalmacije i Kraljevine Hrvatske i Slavonije koja je zadržala kontinuitet hrvatske državnosti od srednjovjekovne hrvatske države.

\section{STARI GRAD U VRIJEME DRUGE AUSTRIJSKE UPRAVE}

\subsection{Stari Grad u administrativnoj strukturi u vrijeme druge austrijske uprave}

Otok Hvar je administrativnom podjelom iz 1823. godine ${ }^{66}$ bio podijeljen na pet općina: Stari Grad, Hvar, Jelsa, Vrboska i Sućuraj, a 1866. godine utemeljena je i općina Bogomolje. U gradu Hvaru bilo je sjedište kotara koji je pokrivao područje čitavog otoka Hvara i kotarskog suda, a ujedno i biskupije i vojne posade. ${ }^{67}$

Godine 1852. utemeljen je i kotarski sud u Starom Gradu ${ }^{68}$ čija se mjesna nadležnost protezala na sve općine na otoku osim one hvarske. ${ }^{69}$

\subsection{Gospodarski i društveni razvoj Starog Grada tijekom 19. stoljeća}

Mletačka Republika nije dopuštala komunama na istočnoj jadranskoj obali gradnju brodova veće kabotaže zbog čega je hrvatsko brodarstvo zaostajalo. Providur Sebastian Barozzi navodi kako 1758. godine samo iz Starog Grada ima čak 40 brodova koji trguju izvan granica Mletačke Republike, međutim radi se o brodovima manje kabotaže. ${ }^{70}$

64 Trogrlić, Marko i Šetić, Nevio (2015.), Dalmacija i Istra u 19. stoljeću, Zagreb, Leykam international d.o.o., str. 56.

65 Maštrović, Vjekoslav (1959.), Razvoj sudstva u Dalmaciji, Zagreb, Jugoslavenska akademija znanosti i umjetnosti, str. 90.

66 Foretić, Dinko (1969.), "Borba za ponarođivanje općina u Dalmaciji (1865-1900)", zbornik Hrvatski narodni preporod u Dalmaciji, Zagreb, Matica hrvatska, str. 90.

67 Stančić, Nikša, "Otok Hvar u vrijeme hrvatskog narodnog preporoda u XIX stoljeću", Zagreb, zbornik Otok Hvar, Matica hrvatska, str. 110.

68 Maštrović, Vjekoslav (1959.), Razvoj sudstva u Dalmaciji, Zagreb, Jugoslavenska akademija znanosti i umjetnosti, str. 73.

69 Stančić, Nikša, "Otok Hvar u vrijeme hrvatskog narodnog preporoda u XIX stoljeću", Zagreb, zbornik Otok Hvar, Matica hrvatska, str. 110

70 Domazet, Mladen (2004.), Suton flote jedrenjaka Starog Grada, Zagreb, DIFO d.o.o., Zagreb, str. 9. 
To s jedne strane upućuje na iznimnu tradiciju pomorskog zanata u Starom Gradu, a s druge strane odražava posljedice četiristogodišnje mletačke kolonijalne politike prema hrvatskim krajevima. I dok kratkotrajna francuska uprava nije pogodovala brodarenju zbog ruske i engleske blokade, austrijske vlasti omogućavaju snažan polet brodarstva i pomorskog poduzetništva. ${ }^{71}$

Uz to se povećala i starogradska flota koja sedamdesetih godina 19. stoljeća broji osamdesetak brodova koji su razvili vrlo razgranatu trgovinu diljem Sredozemlja. ${ }^{72}$

Do druge polovice 19. stoljeća Stari Grad će se razviti u jedno od najvažnijih pomorskih središta ${ }^{73}$ na hrvatskoj obali koje će snažno utjecati na razvoj grada. Sukladno razvitku pomorstva, u istom su razdoblju u Starom Gradu djelovala dva brodogradilišta za velike drvene brodove, ${ }^{74}$ a zbog premještanja plave ribe s tradicionalnih lovišta otoka Hvara i Visa starogradski jedrenjaci nalaze nova ribolovna područja oko otoka Lampeduse te uz sjevernoafričku obalu. ${ }^{75}$

Zbog povećanja lučkog prometa, Pomorska vlada u Trstu proširuje starogradsku obalu $^{76}$ što pored izgradnje novih građanskih kuća postupno mijenja naslijeđeni urbani izgled iz doba mletačke vladavine. ${ }^{77}$

U drugoj polovici 19. stoljeća bilježi se konjunktura vinske trgovine prouzročena bolestima vinograda u Italiji (lug 1850. - 1852.) te u Francuskoj od 1867. do 1892. godine (filoksera). ${ }^{78}$

Ove okolnosti dinamizirale su tradicionalnu strukturu društva u Starom Gradu. Povećava se skupina ljudi pučkog podrijetla koja se bavila trgovinom i brodarstvom. Povećava se broj obrazovanih ljudi, obrtnika i trgovaca te se stvara građanski sloj. ${ }^{79}$

Materijalni napredak u ovom razdoblju omogućio je mnogim težacima, ribarima i pomorcima da pošalju svoje sinove na studije na sveučilišta diljem Monarhije. ${ }^{80}$

Stari Grad u ovom je razdoblju najveće naselje na otoku Hvaru i gospodarsko središte kojemu gravitiraju druga naselja radi trgovine. Zabilježen je i znatan demografski rast tako da na početku druge vinske konjunkture broji 3217 stanovnika, a 1880. godine doseže 3789 stanovnika. ${ }^{81}$

Jezik svakodnevnog života, kao i u svim sredinama pokrajine, bio je hrvatski, u Starom Gradu i okolnim mjestima čakavsko narječje. Stanovnici Starog Grada, i

71 Isto, str. 9.

72 Isto, str. 13

73 Isto, str. 59.

74 Domazet, Mladen (2011.), Stari Grad na Hvaru, otočni grad na razmeđu 19. i 20. stoljeća, Stari Grad, Muzej Starog Grada, str. 20.

75 Isto, str. 29.

76 Isto, str. 55 i 59.

77 Stančić, Nikša, "Otok Hvar u vrijeme hrvatskog narodnog preporoda u XIX stoljeću", Zagreb, zbornik Otok Hvar, Matica hrvatska, str. 109.

78 Isto, str. 109.

79 Isto, str. 109.

80 Isto, str. 109.

81 Domazet, Mladen (2011.), Stari Grad na Hvaru, otočni grad na razmeđu 19. i 20. stoljeća, Stari Grad, Muzej Starog Grada, str. 23. 
čitavog otokg, sebe su nazivali "Harvotima", a svoje čakavsko narječje "harvoskim jazikom".

S druge strane, tijekom četiristoljetnog života pod mletačkom upravom, u višim slojevima dalmatinskog i hvarskog društva oblikovana je tradicija dalmatinske posebnosti zasnovane na općenitoj slavenskoj, a ne na talijanskoj podlozi što se izražavalo pojmom "slavodalmatstva". ${ }^{82}$

\subsection{Političke i društvene prilike u Starom Gradu u pretpreporodnom razdoblju}

Na otoku Hvaru, kao i u čitavoj Dalmaciji, slabo su se osjetila preporodna gibanja iz prve polovice 19. stoljeća u banskoj Hrvatskoj, a zbog nedostataka obrazovanih ljudi hrvatske nacionalne orijentacije još je bila dalja ideja o provođenju nacionalnog pokreta. $^{83}$

U pretpreporodnom razdoblju, najistaknutija osoba u javnom životu čitavog otoka Hvara te dugogodišnji načelnik općine Stari Grad (1818. - 1833.) bio je Petar Nisiteo ${ }^{84}$ Premda odgojen u talijanskoj kulturi i obrazovan u Padovi i Veneciji, te je čitav život pisao talijanski, bio je bio svjestan da je Dalmacija etnički hrvatska pa je u odgovoru na Kukuljevićevu anketu 1858. godine potvrdio da stanovnici Hvara i Dalmacije sebe zovu Hrvatima i govore "slavenskim" jezikom, dok se srpski tvrdio je - nigdje ne govori.

U političkom pogledu podržavao je ideju o sjedinjenju Dalmacije sa sjevernom Hrvatskom, te je 1849. godine bio jedan od potpisnika pozdrava koji je iz Staroga Grada upućen banu Josipu Jelačiću za njegova putovanja Dalmacijom nakon što je bio imenovan guvernerom Dalmacije.

Godine 1860., na početku preporodnih kretanja u Dalmaciji, supotpisao je izjavu iz Staroga Grada kojom nije prihvaćen poziv splitske Općine da se odbije poziv iz sjeverne Hrvatske na sjedinjenje. U izjavi je sjedinjenje podržano, ali u tipičnom slavo-dalmatinskom duhu, uz uvjet da Dalmacija u zajednici sa sjevernom Hrvatskom zadrži određeni vid političke zasebnosti. ${ }^{85}$

\subsection{Prvi izbori za Dalmatinski sabor u Starom Gradu (1861. - 1870.)}

Kao i u ostatku pokrajine, zbog izbornog sustava koji je bio izrazito nepovoljan za hrvatsku većinu, na prvim izborima za Dalmatinski sabor održanima 1861.

82 Stančić, Nikša, "Otok Hvar u vrijeme hrvatskog narodnog preporoda u XIX stoljeću", Zagreb, zbornik Otok Hvar, Matica hrvatska, str. 111.

83 Isto, str. 111.

84 Isto, str. 111.

85 Stančić, Nikša (2018.), str. 111; Milovan Buchberger (2017.), Petar Nisiteo/ posljednji polihistor Dalmacije, Stari Grad: Muzej Staroga Grada, Rad Hrvatske akademije znanosti i umjetnosti, Razred za društvene znanosti 53-535, str. 249-253. 
godine i u izbornim jedinicama u kojima su glasovali birači iz Starog Grada izabrani su slavo-dalmatinski i autonomaški orijentirani zastupnici. U izbornom kotaru gradova Hvar - Stari Grad izabran je autonomaš, zemljoposjednik Jeronim Macchiedo iz grada Hvara, dok je u izbornom kotaru tzv. vanjskih ili seoskih općina Hvar - Brač - Vis, u kojemu su se nalazila i naselja starogradske općine Dol, Selca i Rudine, izabran također autonomaški kandidat Ivan Krstitelj Macchiedo, odvjetnik, dotadašnji načelnik hvarske općine i Jeronim Vusio, sudac Prizivnog suda u Zadru. ${ }^{86}$

Pred izbore za Dalmatinski sabor održane 1864. godine došlo je do podjele između dalmatinskih autonomaša na one koji su podržavali vladinu politiku pokušaja uspostave centralizma i pseudoapsolutizma, tzv. "vladinovce" i one koji su se tome protivili, "liberalne autonomaše" na čelu sa splitskim načelnikom Bajamontijem.

Narodnjaci, na čelu s Mihom Klaićem, nastupili su na izborima zajedno sa skupinom oko Bajamontija, prethodno se privremeno udruživši u tzv. Liberalni savez. Sukob između dviju političkih opcija bio je žestok, osobito u Starom Gradu gdje su autonomaši bili najjači. Zahvaljujući predizbornim savezima u izbornom kotaru gradova Hvar - Stari Grad izabran je liberalni autonomaš Ivan Krstitelj Macchiedo koji je tijekom trajanja zastupničkog mandata prešao u Narodnu stranku.

U izbornom kotaru tzv. vanjskih općina Hvar - Brač - Vis izabran je narodnjak dr. Ivan Vranković iz Starog Grada, a drugi izabrani zastupnik bio je Jeronim Vusio koji je pripadao opciji autonomaša vladinovaca. Međutim na naknadnim izborima održanim 1865. godine umjesto Vusija izabran je narodnjak Vicko Didolić. ${ }^{87}$

\subsection{Općinski izbori (1865. - 1868.)}

Premda su na prvim općinskim izborima koji su se održavali između 1865. i 1868. godine u više od pola općinskih uprava u Dalmaciji pobijedili narodnjaci, na prvim općinskim izborima održanima 1865. u općini Stari Grad najveći broj glasova dobili su liberalni autonomaši koje su poduprli tada još uvijek malobrojni starogradski narodnjaci pa je za načelnika izabran narodnjak dr. Ivan Vranković. Na dužnosti načelnika općine Stari Grad ostaje do saborskih izbora 1867. godine i do razlaza između njega i liberalne autonomaške većine. ${ }^{88}$

Na izborima za Dalmatinski sabor, održanima 1867. godine, uz znatnu potporu vlade posljednji put na izborima ponovno pobjeđuju autonomaši. Bilo bi ih ispravnije nazvati talijanašima jer su njihovi predstavnici u Carevinskom vijeću upravo te godine stupili u klub talijanskih zastupnika prethodno poduprijevši austrougarsku nagodbu koja je postavila ustavnopravnu zapreku ujedinjenja Dalmacije s banskom Hrvatskom. U izbornom kotaru Hvar - Stari Grad, zahvaljujući činjenici što su se dvije frakcije autonomaša ponovno ujedinile, izabran je vođa autonomaša

86 Stančić, Nikša, "Otok Hvar u vrijeme hrvatskog narodnog preporoda u XIX stoljeću", Zagreb, zbornik Otok Hvar, Matica hrvatska, str. 113.

87 Isto, str. 113-114.

88 Isto, str. 114. 
vladinovaca Luiggi Lapenna dok su u kotaru seoskih općina Hvar - Brač - Vis ponovno izabrani narodnjaci dr. Ivan Vranković i Vicko Didolić. ${ }^{89}$

Pobjeda Narodne stranke na saborskim izborima 1870. godine odrazila se na rezultate općinskih izbora u narednom razdoblju pa će narodnjaci povećati broj općina u kojima su imali većinu..$^{90}$

I na samom otoku Hvaru bila je prisutna ista tendencija. U Jelsi je od prvih općinskih izbora općinska uprava pripala narodnjacima zahvaljujući ulozi narodnjački usmjerenom sloju poduzetnika, brodara i posjednika pučkog podrijetla na čelu s obitelji Duboković iz Pitava. U gradu Hvaru nakon prvih općinskih izbora općinsku upravu dijelili su autonomaši i narodnjaci da bi se od 1868. godine na čelu hvarske općine izmjenjivali članovi uglednih hvarskih narodnjačkih obitelji. Slično je bilo i u Sućurju na krajnjem istoku otoka, dok su se autonomaši najdulje zadržali u općinskoj upravi Vrboske, sve do 1901. godine.

Premda treba istaknuti kako mnoge općinske uprave formirane nakon izbora od 1865. godine nisu bile potpuno politički obojene. Često je izborni rezultat bio posljedica kompromisa i mjesnih prilika, a negdje odnosa pristaša jedne i druge političke opcije. Tako je, dok se hvarska općina smatrala autonomaškom, javno izrazila potporu barunu Franji Filipoviću kada se kao namjesnik zalagao za izjednačavanje hrvatskog jezika s tada službenim talijanskim u školama, a Mihovilu Pavlinoviću kod sukoba s Lapennom, uputila je svoje predstavnike na Vis gdje su predstavnici narodnjačkih općina pred Franjom Josipom I. demonstrirali svoje hrvatstvo. S druge strane, nije poduprla Bajamontijev autonomaški miting u Splitu koji su, naprotiv, predstavnici općine Sućuraj, koja je tada smatrana narodnjačkom općinom, podržali. Predstavnici općine Vrboska, koja je smatrana autonomaškom općinom, poput Hvarana, uputili su predstavnike u Vis te također nisu poduprli Bajamontijev miting. ${ }^{91}$

\subsection{Političke prilike u Starom Gradu u preporodnom razdoblju}

Stari Grad je, međutim, ostao među posljednjim općinama, uz glavni grad pokrajine Zadar te Split, Trogir i Vis, u kojima su se autonomaši zadržali na vlasti do 80-ih godina 19. stoljeća. Na to su utjecale specifične mjesne prilike. Naime, na autonomaško opredjeljenje većine stanovnika, preciznije birača težaka i obrtnika, najviše su utjecale dvije iznimno ugledne osobe u mjestu, obojica liječnici iz imućnih obitelji, dr. Dinko Gazzari podrijetlom iz grada Hvara i dr. Marko Nisiteo. Posebno je dr. Gazzari svojim ugledom i naobrazbom privukao gotovo čitavu mlađu generaciju društvenoga sloja iz kojega su inače u Dalmaciji najvećim dijelom dolazili pristalice narodnjaka. Ugled, elokvenciju i empatičnost prema pacijentima koristio

89 Isto, str. 114.

90 Foretić, Dinko (1969.), "Borba za ponarođivanje općina u Dalmaciji (1865-1900)", zbornik Hrvatski narodni preporod u Dalmaciji, Zagreb, Matica hrvatska, str. 133.

91 Isto, str. 135-136. 
je za promicanje talijanaštva prikrivenog dalmatinskim autonomaštvom. Agitatori dr. Gazzarija najčešće su uvjeravali nepismeni puk kako "Harvoti" nisu isto što i "Krovati" (Croati), da su "Krovati" graničari pod puškom i da takva sudbina čeka i Dalmatince ako dođe do sjedinjenja Dalmacije s banskom Hrvatskom.

U vrijeme Liberalnog saveza autonomaši su se podijelili između liberala koje je predvodio dr. Gazzari i vladinovaca koje je predvodio dr. Nisiteo, ali je i nakon ujedinjenja tih frakcija čitav javni život u mjestu bio zaokupljen osobnim sukobom između ovo dvoje liječnika i njihovih pristalica. ${ }^{92}$

S druge strane, narodnjaci su u Starom Gradu ostajali bez svojih najuglednijih osoba. Najistaknutiji narodnjak dr. Ivan Vranković, prvi izabrani načelnik općine Stari Grad i član Pokrajinskog sabora od 1864. do 1900. godine, otišao je u Zadar na mjesto člana Zemaljskog odbora, a 1871. godine u Zadar je otišao i mladi župnički pomoćnik don Juraj Biankini koji je na poziv don Mihovila Pavlinovića preuzeo mjesto urednika narodnjačkog Narodnog lista koji je uređivao sve do talijanske okupacije Zadra 1919. godine. Treba reći kako je Biankini bio dugogodišnji zastupnik u Dalmatinskom saboru (1881. - 1887. i 1889. - 1918.) i zastupnik u Carevinskom vijeću u Beču (1892. - 1918.), utemeljitelj Hrvatskog kluba koji se 1892. godine izdvojio iz Narodne stranke te član izvršnog odbora dalmatinske Stranke prava (1897. - 1905.). ${ }^{93}$

Njima treba pridodati i don Šimu Ljubića, svećenika, povjesničara i arheologa, člana JAZU, također istaknutog sudionika hrvatskog narodnog preporoda $\mathrm{u}$ Dalmaciji koji je, međutim, veći dio života proveo u Zagrebu ${ }^{94}$ i nije izravno sudjelovao u političkim borbama u rodnom mjestu. ${ }^{95}$

Narodnjaci su se prvi put organizirali kod izbora za Carevinsko vijeće 1874. godine, a iste su godine, iako još malobrojni, utemeljili Hrvatsku narodnu čitaonicu. Od tada počinje trajan uspon narodnjaka kojima postupno pristupaju pripadnici nove generacije. ${ }^{96}$

Posebno je značajan dolazak cara Franje Josipa I. Starom Gradu 11. svibnja 1875. godine u sklopu posjeta Dalmaciji. Posjet je, pored Starog Grada, uključivao najvažnija gradska središta pokrajine, Zadar, Split i Trogir. Narodnjaci su iskoristili ovu prigodu za očitovanje hrvatstva Dalmacije te naglašavali carevu titulu hrvatskog kralja, nasljednika krune srednjovjekovnog Hrvatskog Kraljevstva. ${ }^{97}$

92 Stančić, Nikša, "Otok Hvar u vrijeme hrvatskog narodnog preporoda u XIX stoljeću", Zagreb, zbornik Otok Hvar, Matica hrvatska, str. 115.

93 Isto, str. 116.

94 Hrvatska enciklopedija, mrežno izdanje (2020.), "Šime Ljubić", Zagreb, Leksikografski zavod Miroslav Krleža, <http://www.enciklopedija.hr/Natuknica.aspx?ID=37753<.

95 Domazet, Mladen (2011.), Stari Grad na Hvaru, otočni grad na razmeđu 19. i 20. stoljeća, Stari Grad, Muzej Starog Grada, str. 128-129.

96 Stančić, Nikša, "Otok Hvar u vrijeme hrvatskog narodnog preporoda u XIX stoljeću", Zagreb, zbornik Otok Hvar, Matica hrvatska, str. 116.

97 Trogrlić, Marko i Šetić, Nevio (2015.), Dalmacija i Istra u 19. stoljeću, Zagreb, Leykam international d.o.o., str. 59-60. 
I u Starom Gradu bile su izvješene brojne hrvatske trobojnice i zalijepljeni plakati po gradu. Tekst plakata sastavio je don Juraj Biankini, a u njemu podsjeća Franju Josipa I. kako je došao u "gnijezdo starodavne hrvaštine". Ovo su s protivljenjem i prijetnjama zabilježili mjesni autonomaši, a Petar Kuničić bilježi kidanje spomenutih plakata i fizičke sukobe na ulicama. ${ }^{98}$

$\mathrm{S}$ narodnjačkom pobjedom na općinskim izborima u Splitu 1883. godine, izvojevana je odlučna pobjeda hrvatske preporodne ideje u Dalmaciji, nakon čega narodnjaci pobjeđuju i u Visu (1886. godine) te u Trogiru (1888. godine). Na valu uspjeha narodnjaka na saborskim i općinskim izborima, posebno na pobjedi u Splitu, narodnjaci konačno pobjeđuju na općinskim izborima i u Starom Gradu 1887. godine. Za načelnika je izabran mladi liječnik dr. Ante Spalatin. ${ }^{99}$

Ono što je značila za hrvatsku nacionalnu ideju narodnjačka pobjeda u Splitu, isti značaj ima narodnjačka pobjeda u Starom Gradu za otok Hvar. Pored pobjede u jakom dugogodišnjem uporištu autonomaša, ostvareni su konačno i preporodni ciljevi na otoku Hvaru, od pohrvaćenja javnog života, afirmacije hrvatskog nacionalnog identiteta među autohtonim stanovnicima do integracije u hrvatsku naciju u nastajanju kao temelj za ostvarenje glavnog preporodnog cilja koji je u ovoj fazi ostao neostvaren - sjedinjenja Kraljevine Dalmacije i Kraljevine Hrvatske i Slavonije.

\section{ZAKLJUČAK}

Nakon propasti Mletačke Republike 1797. godine, kratkotrajne prve austrijske (1797. - 1806.) i francuske uprave (1806. - 1813.), u trajan posjed nekadašnjih mletačkih posjeda na istočnoj obali Jadrana (tzv. Mletačke Dalmacije i Boke kotorske) kao i nekadašnje Dubrovačke Republike, dolazi Habsburška Monarhija koja formira upravnu jedinicu s određenim stupnjem autonomije. Ona dobiva status krunovine unutar Habsburške Monarhije izravno podvrgnute Beču.

Stari Grad na otoku Hvaru dijeli sudbinu ostalih područja naseljenih Hrvatima na istočnoj obali Jadrana te postaje dijelom austrijske krunovine Kraljevine Dalmacije. Po administrativnoj podjeli iz 1823. godine, Stari Grad je općina koja je dijelom kotara Hvar sa sjedištem u gradu Hvaru, a od 1852. godine je sjedište kotarskog suda koji obuhvaća sve općine otoka Hvara osim samoga grada Hvara.

Do pada Bachova apsolutizma 1861. godine, općine nisu izborno-predstavničke ustanove niti imaju sadržaj ni formu autonomne komune. Međutim, tada središnja austrijska vlast donosi propise koji uvode elemente parlamentarne demokracije na razini pokrajine te lokalne uprave i samouprave na razini kotareva i općina.

98 Domazet, Mladen (2011.), Stari Grad na Hvaru, otočni grad na razmeđu 19. i 20. stoljeća, Stari Grad, Muzej Starog Grada, str. 17.

99 Stančić, Nikša, "Otok Hvar u vrijeme hrvatskog narodnog preporoda u XIX stoljeću", Zagreb, zbornik Otok Hvar, Matica hrvatska, str. 116. 
Uvođenjem elemenata parlamentarne demokracije javljaju se dvije dominantne političke opcije. Jedna od njih protivila se ujedinjenju Kraljevine Dalmacije s banskom Hrvatskom i tražila očuvanje talijanskog jezika kao službenog jezika, rabeći u različitim razdobljima, ovisno o političkim prilikama, isprva slavodalmatinski identitet uz ponekad više, ponekad manje pritajeno talijanaštvo, a u kasnijim prilikama iskazujući otvoreno talijanski identitet. Ovoj opciji suprotstavio se dio građanstva pretežito pučkog podrijetla, afirmirajući hrvatski nacionalni identitet čiji je politički program bio sjedinjenje Kraljevine Dalmacije s Kraljevinom Hrvatskom i Slavonijom, a kao sredstvo tome cilju i uvođenje hrvatskog jezika u upravu, sudstvo, školstvo i javni život. Austrijska državna politika podupirala je pokrajinsku autonomiju jer je stajala na putu hrvatskoj nacionalnoj integraciji te se oslanjala na autonomašku manjinu.

Premda narodnjaci, zbog specifičnog izbornog sustava prema kojemu pravo glasa ima tek $15 \%$ stanovništva, gube izbore za Dalmatinski sabor 1861. i 1864. godine, pobjeda na prvim općinskim izborima, održanima između 1865. i 1868. godine, u većini dalmatinskih općina predstavlja prekretnicu, a 1870. godine pobjeđuju i u izborima za Dalmatinski sabor u kojem više ne ispuštaju većinu.

I premda 1875. godine narodnjaci imaju većinu u tri četvrtine dalmatinskih općina, u Starom Gradu tek predstoji bitka za osvajanje i pohrvaćenje općine. Međutim, zbog specifičnih mjesnih prilika, afirmacija hrvatskog identiteta, a tako i uspjeh Narodne stranke, u Starom Gradu odvija se sporije. Naime, ugled dvojice mjesnih liječnika talijanske nacionalne orijentacije (Gazzari, Nisiteo) poveo je čitavu mlađu generaciju pučkog podrijetla, upravo onog društvenog sloja iz kojeg su u ostatku Dalmacije dolazili pristaše preporodnog pokreta, u autonomaški tabor, što je rezultiralo malim brojem sljedbenika Narodne stranke u početnoj fazi preporodnog pokreta. S druge strane, iz Starog su Grada potekli vodeći ljudi hrvatskog preporodnog pokreta koji, međutim, nisu boravili u Starom Gradu (Vranković, Biankini, Ljubić) i nisu u toj mjeri mogli utjecati na sugrađane. Zbog toga narodnjaci u Starom Gradu pobjeđuju tek nakon afirmiranja sljedeće generacije, sinova starogradskih težaka, ribara i pomoraca školovanih na sveučilištima diljem Monarhije zahvaljujući konjunkturi vinske trgovine i jedrenjačkog pomorstva u drugoj polovici 19. stoljeća.

Narodnjaci pobjeđuju u Starom Gradu na općinskim izborima 1887. godine, četiri godine nakon pobjede u splitskoj općini, kao jedna od posljednjih općina u Dalmaciji.

Zbog različitog povijesnog nasljeđa i mjesnih prilika, preporodni je pokret u Starom Gradu na otoku Hvaru razmjerno kasnio u odnosu na druge općine na otoku Hvaru kao i u odnosu na općine u Dalmaciji, međutim nakon afirmacije nove generacije građanstva pučkog podrijetla, aktivnostima mjesnih narodnjaka te na valu uspjeha narodnjačke opcije na saborskim izborima i izborima za susjedne općine, pogotovo Splita, jačala je svijest o etničkom podrijetlu te o potrebi ostvarenja preporodnih ciljeva. Pobjedama narodnjaka na saborskim i općinskim izborima djelomično su ostvareni preporodni ciljevi, uvođenje hrvatskog jezika u javni život i afirmacija nacionalnog identiteta dok je treći i najvažniji cilj - sjedinjenje 
Kraljevine Dalmacije s banskom Hrvatskom - ostao neostvaren. Međutim, rezultat preporodnog pokreta jest svijest o potrebi ostvarenja tog cilja i uopće ujedinjenja hrvatskih zemalja među pobornicima preporodnog pokreta te je prenesen sljedećim generacijama.

\section{LITERATURA}

1. Bartulović, Željko (2008.), Povijest hrvatskog prava i države (nacrt predavanja za internu uporabu), Pravni fakultet Sveučilišta u Rijeci.

2. Bartulović, Željko i Ranđelović, Nebojša (2012.), Osnovi ustavne istorije jugoslovenskih naroda, Pravni fakultet u Nišu, Niš.

3. Buchberger, Milovan (2017.), Petar Nisiteo: posljednji polihistor Dalmacije, Stari Grad: Muzej Staroga Grada.

4. Cetnarowicz, Antoni (2006.), Narodni preporod u Dalmaciji, Zagreb, Srednja Europa.

5. Domazet, Mladen (2011.), Stari Grad na Hvaru, otočni grad na razmeđu 19. i 20. stoljeća, Stari Grad, Muzej Starog Grada.

6. Domazet, Mladen (2004.), Suton flote jedrenjaka Starog Grada, Zagreb, DIFO d.o.o., Zagreb.

7. Foretić, Dinko (1969.), "Borba za ponarođivanje općina u Dalmaciji (1865-1900)", zbornik Hrvatski narodni preporod u Dalmaciji, Zagreb, Matica hrvatska, str. 86-190.

8. Hrvatska enciklopedija, mrežno izdanje (2020.), "Šime Ljubić", Zagreb, Leksikografski zavod Miroslav Krleža, <http://www.enciklopedija.hr/Natuknica. aspx? ID $=37753<$.

9. Maštrović, Vjekoslav (1959.), Razvoj sudstva u Dalmaciji, Zagreb, Jugoslavenska akademija znanosti i umjetnosti.

10. Mrduljaš, Saša (2019.), "Etnički sastav naselja Boke kotorske prema popisu stanovništva iz 1900. godine", Migracijske i etničke teme, vol. 35, br. 3, str. 241-276.

11. Novak, Grga (1969.), "Narodni preporod u Dalmaciji", zbornik Hrvatski narodni preporod u Dalmaciji i Istri, Zagreb, Matica hrvatska, str. 77-85.

12. Novak, Grga (2004.), Prošlost Dalmacije, knjiga druga, Split, Marjan tisak d.o.o.

13. Pilar, Ivo (1990.), Južnoslavensko pitanje, prikaz cjelokupnog pitanja, Varaždin, Hrvatska demokratska stranka, Podružnica Varaždin.

14. Stančić, Nikša, "Otok Hvar u vrijeme hrvatskog narodnog preporoda u XIX stoljeću", Zagreb, zbornik Otok Hvar, Matica hrvatska, str. 109-116.

15. Trogrlić, Marko i Šetić Nevio (2015.), Dalmacija i Istra u 19. stoljeću, Zagreb, Leykam international d.o.o. 


\section{STARI GRAD ON THE ISLAND OF HVAR IN CROATIAN FOLK REVIVAL - ADMINISTRATIVE STRUCTURES AND POLITICAL LIFE}

The collapse of the Venetian Republic in 1797, the first Austrian (1797-1806) and French administration (1806-1813), after which the Venetian estates (Venetian Dalmatia and the Bay of Kotor) and the former Republic of Dubrovnik came to power, formed the Habsburg Monarchy administrative unit - the Kingdom of Dalmatia, directly subordinated to Vienna.

The paper is an overview of the structure of the administration and judiciary, the political situation until 1848 and 1861, when elements of parliamentary democracy and local self-government were introduced through the Dalmatian Parliament in Zadar. Until the fall of Bach's neo-absolutism in 1861, municipalities were not electoral-representative institutions. Two political options emerge, one opposing the unification of Dalmatia with Croatia, seeking the Italian language as the official language, emphasizing first the Slavo-Dalmatian and later the Italian identity (Italians, autonomists). In contrast, part of the citizens, mostly of popular origin, affirms the Croatian identity, seeks the unification of Dalmatia with Croatia and Slavonia, and the introduction of the Croatian language in the administration, judiciary, education (populists, annexationists). Vienna supports the autonomists, not wanting Croatian national and state integration. Due to the electoral system, the Narodnjaci lost the elections to the Dalmatian Parliament in 1861 and 1864, but won the first municipal elections in $1865-1868$, and in 1870 the elections to the Parliament.

The rest of the paper deals with the specifics of the Stari Grad, where the affirmation of the people is slower. Stari Grad has been a municipality since 1823, part of the Hvar district, and since 1852 the seat of the district court. The reputation of local autonomist medical doctors (Gazzari and Nisiteo) led the younger generation of Croatian people to their camp, although some of the leading figures originated from Stari Grad (Vranković, Biankini and Ljubić). The political party Narodnjaci won in 1887, when the next generation of Croatian intelligentsia was established, the sons of common people (farmers, fishermen and sailors) were strengthened by the development of the economy - wine trade and maritime affairs in the second half of the 19th century.

Key words: Stari Grad, admin istrative and political structures, political situation 